INCENTIVE CONFLICT IN CENTRAL-BANK RESPONSES

TO SECTORAL TURMOIL IN FINANCIAL HUB

COUNTRIES

Edward J. Kane

WORKING PAPER 13593 
NBER WORKING PAPER SERIES

INCENTIVE CONFLICT IN CENTRAL-BANK RESPONSES TO SECTORAL TURMOIL IN FINANCIAL HUB COUNTRIES

\author{
Edward J. Kane \\ Working Paper 13593 \\ http://www.nber.org/papers/w13593 \\ NATIONAL BUREAU OF ECONOMIC RESEARCH \\ 1050 Massachusetts Avenue \\ Cambridge, MA 02138 \\ November 2007
}

The author wishes to thank Ramon P. DeGennaro, Robert A. Eisenbeis, Richard Herring, James Moser, and James Thomson for comments that greatly improved the paper. The views expressed herein are those of the author(s) and do not necessarily reflect the views of the National Bureau of Economic Research.

(C) 2007 by Edward J. Kane. All rights reserved. Short sections of text, not to exceed two paragraphs, may be quoted without explicit permission provided that full credit, including $\odot$ notice, is given to the source. 
Incentive Conflict In Central-Bank Responses to Sectoral Turmoil in Financial Hub Countries

Edward J. Kane

NBER Working Paper No. 13593

November 2007

JEL No. E58,F33,G21,G28

\begin{abstract}
$\underline{\text { ABSTRACT }}$
National safety nets are imbedded in country-specific regulatory cultures that encompass contradictory goals of nationalistic welfare maximization, merciful treatment of distressed institutions, and bureaucratic blame avoidance. Focusing on this goal conflict, this paper develops two hypotheses. First, in times of financial-sector stress, political pressure is bound to increase the incentive force of the second and third goals at the expense of the first. Second, gaps and distortions in cross-country connections between national safety nets require improvisational responses from de facto hegemonic regulators. Reinforced by reputational concerns, the hegemons' goal conflicts dispose them to react to cross-country evidence of incipient financial-institution insolvencies in short-sighted ways. During the commercial-paper and interbank turmoil of summer 2007, de facto hegemons used repurchase agreements to transfer taxpayer funds -- implicitly but in large measure -- to several of the particular institutions whose imprudence in originating, pricing, and securitizing poorly underwritten loans led to the turmoil in the first place. The precedent established by these transfers promises to exacerbate the depth, breadth, and duration of future instances of financial-institution insolvency by confirming that institutions that underinvest in due diligence can expect taxpayers to protect them from much of the adverse consequences.
\end{abstract}

Edward J. Kane

Department of Finance

Boston College

Chestnut Hill, MA 02467

and NBER

edward.kane@bc.edu 


\section{INCENTIVE CONFLICT IN CENTRAL-BANK RESPONSES TO SECTORAL TURMOIL IN FINANCIAL HUB COUNTRIES}

Political concern for the safety of a particular enterprise or economic sector increases both with its clout and with the extent to which its failure might generate negative externalities that harm voters and so-called "innocent parties" that cannot directly influence the tradeoffs its managers make. Implicitly or explicitly, most governments maintain a safety net for banks and selected other firms. This net combines measures that restrict the risky positions that protected institutions assume in the first place with measures that limit the damage that customers, employees, creditors, and stockholders suffer when and if disaster ensues. Managers of protected institutions may be likened to a team of high-wire artists. They deliberately throw themselves into risky positions and, when things turn out badly, a messy multiparty disaster can ensue.

Section I of the paper identifies the conceptual components of a national safety net and describes the incomplete ways that the nets of financial-center countries are joined today. Section II introduces the idea that national regulatory cultures exist and embrace conflicting norms. Section III develops the hypothesis that financial turmoil alters the preference ordering that regulatory cultures assign to conflicting regulatory norms. In times of turmoil, the incentive force exercised by norms that foster truth-telling and accountability for efficient and distributionally defensible loss control declines sharply, while the influence of competing nationalistic and blame-minimization norms intensifies. For the leaders of the hegemonic global regulatory community (especially the Fed and the European Central Bank), the absence of an established procedure for sharing losses that might be imbedded in the accounts of large multinational institutions increases the 
depth of their exposure to a personal and bureaucratic reputational disaster. To reduce this exposure, policymakers in these countries can use central-bank lending to shift some of the worrisome losses to national taxpayers by directly and indirectly subsidizing troubled financial markets and institutions that lie within their purview whenever it appears that financial-institution insolvencies may be widespread. Officials’ reputational concerns and limited policy options combine to create a disposition to over-react to multinational financial stress (such as that observed during the 2007 subprime turmoil). In the US, this disposition implies that having a corporate subsidiary with primary-dealer status opens a channel through which a few deeply troubled foreign conglomerates and domestic nonbanks can plan to extract substantial subsidies by engaging in repurchase agreements with the Fed.

Current market turmoil may be attributed to the market's simultaneous reassessment and repricing of the downside risks inherent in securitization vehicles that outsourced the due-diligence phase of the underwriting process to credit-scoring models and credit-rating organizations. For example, trading in the riskiest slice of the ABX index of bonds backed by home loans made in the second half of 2006 slid to a new low of 18 cents by late October, while the TABX index (which proxies the assets underlying collateralized debt obligations) has also continued to slide.

The reassessment and repricing clogged the pipeline of unfinished securitizations, particularly for institutions and conduits that originated or packaged the riskiest loans or securitization structures. In addition, the repricing undermined the solvency of highly leveraged institutions (such as structured investment vehicles) that had routinely shortfunded a risky portfolio. 
Although using central-bank resources to relieve insolvency-driven shortages of liquidity at troubled institutions keeps markets running more smoothly in the short run, it generates adverse long-run consequences by allowing institutions to reap rewards in proportion to the imprudence they showed in originating, pricing, and securitizing poorly underwritten loans. Accommodating their needs threatens to exacerbate the depth, breadth, and duration of future instances of financial-institution insolvency by encouraging these and other institutions to underinvest in due diligence in the future. Section IV explains that, to offset short-run pressure on central banks to give troubled institutions a break, it is important to require officials to follow market-mimicking procedures in curing so-called liquidity shortages and to justify and account explicitly for the value and distribution of the subsidies their last-resort lending generates.

I. Understanding National Safety Nets and How Weakly They are Linked

Financial stability is often defined by contraposition: as the absence of widespread liquidity and solvency crises. An enterprise experiences a liquidity crisis when it finds it difficult and/or inordinately expensive to refinance its debt or to meet other obligations as they come due. A liquidity squeeze is usually rooted in an overleveraged balance sheet or an unsupportable business plan. In other cases, lending institutions should be able to recognize a firm's legitimate credit needs. However, when financial institutions in a given nation or region undergo serious liquidity crises of their own, their ability to support the liquidity needs of viable customers can be temporarily disrupted. 
The desirability of preventing the dissolution of fundamentally healthy firms creates a logical case for the existence of private or governmental lenders of last resort (Thornton, 1802; Bagehot, 1873).

A troubled firm falls into insolvency when the discounted value of its accumulated and projected losses exceeds its capacity to absorb these losses. For an individual nation, a corporate insolvency crisis amounts to a tsunami of individual-firm red ink. A financial tsunami occurs when losses passed into the accounts of at least one systemically important financial-services firm or sector overwhelm its enterprisecontributed capital and are perceived to be spilling rapidly into the balance sheets of various counterparties. The crisis is propagated by the political and economic efforts of potential loss-bearers to shift their contractual exposure to the tidal wave of losses onto less-wary parties, especially ordinary taxpayers.

A nation's financial safety net has three goals: (1) avoiding liquidity and insolvency crises; (2) identifying and alleviating temporary liquidity shortages (i.e., “disorderly markets”); and (3) mitigating the effects of both isolated and widespread insolvencies when they surface. The fabric of the net combines arrangements intended to detect and contain developing financial-institution problems with politically feasible arrangements for absorbing and distributing losses protected institutions might incur. This paper argues that, whereas national safety nets in hub countries may be likened to a relatively sturdy nylon mesh, the fabric connecting these nets is tissue-thin. For safetynet managers, the cross-country tissue fails to establish global accountability for the knock-on economic effects of the policies they follow. Without such accountability, national authorities are free to maximize a myopic and self-determined welfare function 
that they need not worry about revealing or defending ex post. Given so much discretion, global safety-net support is unlikely to be allocated in distributionally defensible or costeffective ways either within or across nations (cf. Todd, 2002).

Systemic risk concerns the chance of a system breakdown or devolution. Breakdowns may come from damage that spreads contagiously from one part of a network to another or from the disintegration of one or more network connections. Within a country, systemic risk expresses the danger is that a wave of insolvencies will suddenly interfere with payments and credit flows between regions and major institutions. In a global context, systemic risk is the risk that losses embodied in one nation's wave of insolvencies will batter firms and households located on foreign financial shores. By expanding opportunities for transferring local risks across countries at low cost, globalization helps to reduce the concentration of idiosyncratic risks in individual nations. But at the same time, intrafirm and hub-and-spoke linkages between the financial-services firms and markets of individual nations provide opaque channels through which the destructive energy unleashed by one country’s liquidity shortage or insolvency crisis and its speed of transmission to other countries might actually be amplified.

Regulatory lags in adapting to cross-country securitization has left the tissue connecting national safety nets dangerously thin. National markets for interbank loans and financing customer needs are integrating faster through intrafirm and hub-and-spoke linkages than arrangements for mitigating the consequences of cross-country shocks. By default, responsibility for managing global crisis pressures falls upon a handful of incentive-conflicted national regulatory institutions and cross-country lenders of last 
resort. To understand how these pivotal institutions might interact in different kinds of global crises, one must recognize that inconsistent constraints and incentives are built into the norms that govern the political and regulatory cultures within which their managers operate.

\section{Components of National Nets}

Modern finance theory emphasizes that financial-institution customers and safetynet managers must control incentives for opportunistic behavior by financial-institution managers, owners, and borrowers (Jensen and Meckling, 1976; Diamond, 1984; La Porta, Lopez-de-Silanes, Shleifer, and Vishny, 1998). Managerial opportunism has three intertwined roots:

1. Monitoring costs: difficulties outsiders face in obtaining reliable information about unfavorable developments and observing adverse actions by institution managers, including recklessness, negligence, incompetence, fraud, and selfdealing;

2. Policing costs: difficulties outsiders face in adequately analyzing and responding to whatever information its monitoring activity uncovers;

3. Coordination costs: difficulties customers and national safety-net managers face in coordinating collective action.

Safety nets centralize the functions of monitoring, analyzing, and responding to evidence about institutional performance. Ideally, this outsourcing of due diligence helps financial institutions to maintain customer confidence by solving three coordination problems: avoiding redundant monitoring expense; standardizing contracting protocols; and timing and calibrating disciplinary action. When its incentives are aligned with 
society’s needs, a conscientious monitor-enforcer will make it unprofitable for institutions to misrepresent their economic condition to customers and to pursue profitmaking opportunities that unfairly exploit their informational advantages.

Viewed as a bureaucratic structure, a safety net has three components: (1) financialinstitution regulators and monitors; (2) lenders of last resort; and (3) regimes for financing safety-net activities and allocating the losses imbedded in insolvent enterprises. This architecture is supported by a social contract whose counterparties are major sectors of a nation's political, regulatory, and economic communities. In principle, the contract has three segments:

1. Subcontracts that define and assign supervisory responsibilities for preventing and resolving disruptive financial-institution insolvencies;

2. Subcontracts that define a range of tax-transfer techniques for financing this supervisory activity and whatever losses it fails to prevent;

3. Subcontracts that dictate the political and economic incentives under which such safety-net operators discharge their responsibilities.

\section{Tissue Connecting National Nets in Open Economies}

Regulators in hub countries are well aware of the need to stretch the span of their safety nets to match the span of the markets and institutions under their purview. However, they lack the authority to tax or compensate foreign entities directly as global stability might require. The connections forged to date focus mainly on guarding against crises in good times and hardly at all on how to deal with crises when they occur (Eisenbeis and Kaufman, 2005). 
Two world-spanning portfolio institutions were established in 1944 at Bretton Woods: the International Monetary Fund (IMF) and the World Bank. Unlike the "Fund" which can operate somewhat like a bank, the "Bank" operates as a fund that cannot provide timely crisis assistance. The European Central Bank (ECB) is an important and more recent regional portfolio institution. Its monetary-policy activities span the markets of Euro-area countries.

National safety nets are also linked by a series of less-comprehensive international financial organizations. These bridging organizations are of two types: (1) portfolio institutions to which member countries have contributed funds that their managers invest in particular kinds of assets and (2) intergovernmental and self-regulatory forums for coordination (such as the Financial Stability Forum and Financial Stability Institute) that serve primarily to debate, evaluate, and secure agreement on rules and standards for overseeing cross-border business in a club-like atmosphere.

At least six worldwide coordinating forums deserve mention: the World Trade Organization (WTO), the Bank for International Settlements (BIS), the International Organization of Securities Commissions (IOSCO), the International Association of Insurance Supervisors (IAIS), and the International Association of Swaps Dealers (IASD).

Functioning within the BIS, the Basel Committee on Banking Supervision (BCBS) leads the way in formulating cross-country standards for banks. Regionally, the European Commission develops economic policy guidelines for European Union (EU) countries. These last two forums have developed the principle that primary responsibility 
for the solvency of multinational financial conglomerates lies with home-country regulators.

Arguably, only the BIS, the ECB, and the IMF establish financial and regulatory tissue that meaningfully connects the supervisory activities and fiscal resources that constitute financial nets in different countries. These three institutions seek to persuade individual countries to identify and adopt improved safety-net arrangements. However, only the ECB can truly create money and is able to react promptly enough to assist troubled institutions and markets when they fall into distress.

Because none of these institutions has the authority to levy taxes at will, their managers cannot overtly allocate losses in crisis circumstances. Whatever subsidized crisis assistance these entities can supply must flow through some form of last-resort lending.

This paper makes three points:

1. The global net enlarges the web of multiparty contractual duties and obligations facing managers of national nets. The links concern the deployment of implicit government guarantees and subsidized lender-oflast-resort credit facilities.

2. Central-bank repurchase agreements have evolved into a particularly opaque substitute for discount-window lending.

3. The absence of a global tax-transfer mechanism for resolving the insolvency of multinational conglomerates is apt to call forth an inflationary oversupply of subsidized last-resort lending from central banks 
in financial hub countries when substantial multinational shocks first emerge.

\section{Incentive Conflicts Built into National Regulatory Cultures}

In a democracy, financial regulation and supervision are cooperative endeavors. Anyone can propose rules, but to command compliance requires legitimacy: a mutual understanding that the rules are conceived and enforced to increase the social welfare of an identifiable community.

\section{Dimensions of Regulatory Culture}

To win and sustain a legitimate right to wield coercive force on behalf of a larger community, regulators must accept and respect appropriate checks on their authority. An "appropriate" check is one that incentivizes regulators to act in ways that are consistent with the community's political institutions and its citizens' understanding of the community's past regulatory experience.

A culture is defined as customs, ideas, and attitudes that members share and transmit from generation to generation by systems of subtle and overt rewards and punishments. Carnell (1993) and Kane (2003) assign regulatory culture the role of defining, authenticating, and promoting the financial common good. One country's regulatory culture may differ from another's along as many as six dimensions:

1. in the character of the statutory grant of authority, the reporting responsibilities, and governance structure that a regulatory enterprise receives;

2. in the specific rules the enterprise formulates and how it develops and promulgates them;

3. in the methods the enterprise uses to monitor for violations; 
4. in the penalties it can or does impose on clients when it finds material violations;

5. in the nature and extent of due-process restrictions (including specific burdens of proof) that protect regulated institutions from unfair administrative procedures;

6. in the character of institutions' rights to appeal regulatory decisions to a higher authority.

The taboos and traditions incorporated in a regulatory culture take the form of norms that embody community goals and standards of fair play and proper use of government power. The first four dimensions of the culture set limits on safety-net managers' authority over their regulatees. Along with banks' rights to challenge and appeal adverse actions, the final two dimensions of a regulatory culture provide credible ways for regulators to bond themselves to exercise their authority in the joint interests of financial institutions and their various creditors and counterparties.

\section{Importance of Transparency and Deterrency}

To complete the cycle of social-contract enforcement, the suppliers of regulatory risk capital—-healthy institutions and ordinary taxpayers—-must be able to observe and discipline the economic value of their stake in the rulemaking and enforcement activities that regulators undertake. Ideally, savvy taxpayers would impose reporting requirements and establish deterrent rights sufficient to persuade net managers to deploy their examination, supervisory, and lending powers at reasonable economic cost to society as a whole. Also ideally, these costs would be measured comprehensively and include both the costs of operating the net and the costs of managing its occasional breakdown. Taxpayer ability to monitor regulators is important because the co-operative nature of financial regulation and the exercise of appeal rights by regulated institutions would 
otherwise tend to make regulatory personnel overly responsive to industry concerns (i.e., subject them to regulatory “capture”).

\section{What if Monitoring and Policing Costs Were Zero?}

Regulators' tools of damage control are rulemaking and enforcement. To understand the economic role these tools play, it is helpful to imagine a world in which customers' monitoring and policing costs are uniformly zero. In this world, financial contracts would not need external enforcement. Coordination costs would be irrelevant. Establishing a team of centralized monitors and enforcers to thwart risk-shifting and misconduct by bank insiders would offer no incremental benefit either to institutions or to their customers. In such a world, changes in an institution's condition and risk exposure would be transparent to everyone and counterparties would possess sufficient expertise and sanctions to deter an institution's insiders from trying to take advantage of them.

Maximal transparency (MT) describes a framework of disclosure that would perfectly and costlessly inform customers about changes in bank or fund performance and risk-taking activities. To set up an easy-to-remember rhyme, we coin the term maximal deterrency (MD) to describe a situation in which customers would immediately and perfectly understand the implications of information flows and would be able to protect themselves completely and costlessly from whatever threat to their wealth this information might reveal.

The more closely an economy comes to offering creditors maximal transparency and maximal deterrency, the less ex ante value that financial institutions and safety-net managers can create for their counterparties. In an MTMD economy, cash in advance and credit could substitute perfectly for each other in every payment context. Similarly, 
direct and indirect finance would provide equally economical ways of mobilizing savings, of choosing which real investment projects savers ought to support, and of deciding how to price project risk. As envisaged in the Capital Asset Pricing Model, corporate and government securities could be offered in denominations small enough to allow virtually every individual saver to invest directly in a diversified portfolio of stocks, bonds, and derivative securities.

The MTMD thought experiment clarifies that safety nets owe their existence to market imperfections which include: difficulties of contract enforcement; blockages in information flows; differences in monitoring costs; variation in financial transaction costs; delays in appreciating and processing relevant information; and the costliness and inadequacy of the deterrent remedies that individual depositors have available to them. It also clarifies that a national safety net is implicitly a six-party contract. The net imposes mutual rights and duties on: institutions, investors, borrowers, depositors, safety-net managers, and suppliers of safety-net capital (principally healthy banks and taxpayers). The touchstone by which to judge the performance of safety-net managers is how fairly they treat each of the many counterparties participating in their social contract and how efficiently they control the diverse social costs of coping with divergences from MT and MD conditions.

III. Global and National Incentive Conflicts in Safety-Net Management In practice, national safety-net managers assemble a staff that can wield six categories of regulatory instruments:

1. record-keeping and disclosure requirements;

2. activity limitations; 
3. capital, loss-reserving, and other position limits;

4. takeover rights and other enforcement powers;

5. lines of credit; and

6. performance guarantees.

It is not enough for safety-net managers to use these instruments to block corrupt and unwise flows of institutional credit and avoid customer runs. They must seek also to minimize the social damage caused by temporary bouts of illiquidity and by lasting insolvencies. Moreover, to administer lender-of-last-resort facilities properly, safety-net managers must perform a financial triage function. This begins by identifying solvent, but illiquid institutions and shielding them from having to sell assets into momentarily disorderly markets at fire-sale prices. But efficient triage must also establish an accountable procedure for identifying and either winding up or recapitalizing insolvent institutions.

What Countries Manage the Global Safety Net?

Arguably, procedures for developing recommendations and controlling the portfolio activity of supranational institutions give disproportionate weight to the interests of the US, Britain, and the few other countries that function as global hubs. For example, in the Basel Committee on Banking Supervision, the US has four representatives and Britain two. This overweighting is no accident. Only a few national money markets have forged strong interinstitutional links with one another. While intrainstitutional linkages are extremely important, most cross-border institution-to-institution business (especially, securitizations and derivatives transactions) flows to and from major financial-services 
firms headquartered in global hub countries. To understand who manages systemic risk globally, one must first identify these hub countries.

Wojcik (2007) measures the value of international financial-services business currently performed by firms headquartered in 41 leading countries. His index shows that this product line is dominated geographically by firms headquartered in the UK, US, and Euro area (especially Germany, France, and The Netherlands). Other countries perform much less international financial service.

The UK produces roughly 30 percent of the relevant services, followed by the US which supplies another 20 percent. Euro-area countries furnish 28 percent, although a good portion of this is probably transacted among area countries. Even though each of the following countries is among the world's top-ten producers, Hong Kong, the Caymans, Japan, and Switzerland book only 12 percent of the market among them. Australia and Canada handle another 3 percent. The last 7 percent of the market is shared by 19 other countries.

\section{Differences in Hub-Country Cultures}

The first dimension of any regulatory culture establishes a bureaucratic structure for managing particular portions of the net. In the hub countries we have identified, this structure is multidimensional and generates a number of uncomfortable incentive conflicts.

In the UK, the tasks of making and carrying out monetary-policy decisions and of monitoring financial-institution loss exposures are assigned to different organizations. The Bank of England is tasked with stabilizing the real economy and financial markets, while the Financial Services Authority (FSA) handles financial supervision. In the US, 
The Federal Reserve System jointly pursues both tasks. Additional incentive conflicts come from the Fed's need to share (and compete for) rights to supervise variously chartered institutions with other agencies. In theory, the Fed's interest in competing for regulatory turf--both globally and with other US agencies--adds goals and restraints to its monetary policymaking process and regulatory culture that the Bank of England (B of E) faces in more overtly political ways.

Although the Fed is the sole supervisor for the US holding companies that ultimately book the vast majority of America’s cross-country loss exposures, by converting its national-bank subsidiary to a federally chartered thrift in March 2007, Countrywide Financial cleverly moved itself into the mortgage-market friendly jurisdiction of the Office of Thrift Supervision and extricated itself from direct supervision by the Fed and OCC. Moreover, as mortgage-market turmoil expanded, Fannie Mae and Freddie Mac sought to expand their role in stabilizing mortgage markets at the expense of the Fed. The policy significance of this intensification in regulatory competition has increased as mortgage-market turbulence became more and more prolonged.

In the global arena, the B of E competes for jurisdiction with both the Fed and the ECB. Like the B of E, the ECB conducts monetary policy (jointly for Euro-area countries) and has to leave supervisory activities to other parties: the member nations to whom it is politically accountable. However, unlike the B of E, in an emerging crisis, the ECB does not have a discount window and must adapt its decisions about substitute forms of last-resort lending to the needs that individual-country regulators put forward. 
These differences in supervisory responsibility and channels for clientele influence are bound to affect the amount and quality of information available to centralbank personnel at the outset of either type of crisis. In particular, with only a few large domestic organizations to investigate, one might have thought that B of E personnel would be able to separate liquidity shocks from solvency shocks more quickly and more effectively than either the Fed or ECB can. However, the B of E's handling of the Northern Rock episode throws both hypotheses into doubt.

Principal-agent theory indicates that incentive conflicts driven by regulatory competition and clientele pressure for relief explain, at least in part, the different patterns of diagnosis and initial response during the August 2007 subprime turmoil. The B of E's initially hard-line response to FSA requests for it to help UK mortgage lenders indicates that it did not see hedge-fund failures and wholesale writedowns of mortgage-backed and other structured securitizations as posing as great a threat to real economic activity as spokespersons for the two other hegemonic central banks vigorously proclaimed. Governor Mervyn King stressed a concern for mitigating moral hazard that spokespersons for the FSA, ECB, and the Fed downplayed (Shieritz and Wiesmannin, 2007).

\section{Repurchase Agreement As Particularly Opaque Last-Resort Loans}

Even in emergencies, the Fed's discount window is ordinarily available only to institutions chartered in the US and their condition and need for funds are reviewed before a loan is dispersed. In contrast, repurchase agreements are put out at auction to a previously designated set of 21 "primary dealers" in securities. As Table 1 indicates, eligible counterparties include subsidiaries of Countrywide Financial (the largest 
originator of zero-equity and nonamortizing mortgages in the US) and eleven foreign conglomerates (including HSBC whose US subsidiary was also an aggressive mortgage lender). Although interaffiliate loans from bank subsidiaries of US holding companies are restricted by the Fed's Regulation W and Section 23A of the Bank Holding Company Act, other primary dealers were able to on-lend the proceeds from Fed repos to affiliated parties without restriction. When the subprime turmoil intensified in early August 2007, several troubled mortgage lenders and selected hedge-fund sponsors (Countrywide, HSBC, and Bear Stearns) and foreign institutions (whose opportunity cost for funds were rising sharply) were likely both to bid aggressively for repo funds and to enjoy substantial subsidies on whatever funds they managed to raise in this way. Around August 20, the Fed used its authority to exempt banking organizations from 23A limits to grant Citigroup, JPMorgan Chase, and Bank of America a parallel (albeit temporary) right to engage in well-collateralized securities financing transactions with their affiliates. $\underline{\text { How Repurchase Agreements Substitute for Discount-Window Loans }}$

Traditionally, last-resort loans have been disbursed through the discount window and offered only to banks. In the midst of either a liquidity or insolvency crisis, lastresort lending to a restricted class of borrowers inevitably delivers implicit subsidies to members of the favored class. What we may call the subsidy-minimization norm of lastresort lending requires that subsidy-minimizing collateral requirements be imposed and that contract interest rates show a substantial premium over rates observed on less-risky securities in the open market.

Even though many nonbank institutions are eligible for emergency central-bank loans today, penalty rates and collateral requirements make it costly and even dangerous 
for deeply distressed nonbank firms to meet their liquidity demands through the discount facility. For a firm that is in or approaching insolvency, central-bank insistence on charging reasonable risk premiums and enforcing collateral standards raises the opportunity cost to borrowers of tying up eligible assets. Although in difficult circumstances central banks can and do lend at a lower premium and relax the collateral requirements they enforce, managers of deeply troubled institutions often fear the bad publicity that last-resort borrowing might generate. This publicity can intensify the market pressure that a borrowing firm faces, in that it can lead private creditors (including other banks) to demand higher rates or stronger collateral support in private deals that might otherwise have carried less-onerous terms. For deposit institutions during August 2007, the longer maturities, low costs, and nonstigmatized character of Federal Home Loan Bank (FHLB) advances made the FHLB system the preferred source of government loans (Dudley 2007).

From the central-bank perspective, when funds are supplied through the discount window, borrowers hold the initiative and contract terms must conform to the posted schedule of discount rates and eligibility requirements. At the discount window, borrowers also decide when and for how long they want to borrow and what collateral they will offer. Central banks have discovered that they can use repurchase agreements (“repos”) to undertake last-resort lending in a more flexible and less stigmatized way. By actively bidding for repos an incipient crisis, a central bank can assure knowledgeable parties that the collateral it is prepared to accept includes the particular assets whose markets, originators, and securitizers seem most sorely distressed. It can also shade its range of acceptable collateral to favor specific counterparties and set the maturity and 
price of particular deals without regard to the declared structure and terms of discountwindow lending.

As valuable as this flexibility might be in times of turmoil, it is also dangerous. The danger is that nonbank institutions such as hedge funds, aggressive mortgage lenders, and investment- bank subsidiaries of domestic and foreign conglomerate firms that experience substantial demands for redemption from their investors and other counterparties will be able to misrepresent the character and to understate the extent of the unbooked losses driving their distress. Moreover, insolvent institutions can fuel regulatory competition by lobbying on behalf of other agencies in competing jurisdictions (such as Fannie Mae and Freddie Mac in the US) that might be eager to help them when and if the central bank does not.

Libor is the interest rate at which US and foreign banks lend to one another. Figure 1 shows that in August, 2007 overnight interest rates for banks in different nations and currencies responded differently to the onset of liquidity pressure. UK banks faced higher rates in the Euro market than either US or Eurozone banks did. This indicates that foreign banks suspected that some British institutions might be holding or temporarily warehousing a disproportionate share of the particular kinds of credit risk that were being reassessed and repriced. Because the US federal-funds rate lay well below the Fed's 5.25 percent target and the Euro-market rate for dollars for most of the next month, one may infer that US banks were reluctant to borrow fed funds to onlend them in Europe.

In the US, liquidity pressure focused not on banks per se, but on securitizers of opaque pools of loans. Figures 2 shows that, while the volume of commercial paper fell 
sharply when the turmoil first surfaced, the decline was concentrated in asset-backed paper. Moreover, even this market segment began to recover within a couple of weeks. Figure 3 clarifies two points. First, in the US liquidity never truly dried up. Newissue markets for AA-rated commercial paper remained active through every day of the turmoil period. Second, while the volume of all three types of issues declined in the week before the Fed's injection of liquidity on August 10, the sharp decline in the assetbacked segment was from a monthly high. Within two weeks, the volume of new issues in that segment had recovered and was fluctuating much less than in July.

These data (and the failure and government rescue of a few German and British banks) indicate that a market-driven triage process came into play as soon as the quality of underwriting standards embodied in mortgage-backed and complex securitizations came under fire. The market response was to require better documentation and stronger collateral from originators and conduits and to eschew questionable pools of loans. The regulatory response was to use primary dealers to flood troubled institutions and markets with funds. To justify this, officials characterize themselves as merely remedying a shortage of market "liquidity" rather than bailing out a set of institutions (including structured investment vehicles and their sponsors) that chose to compound their already substantial exposure to default risk with an interest-rate bet that posed potentially ruinous levels of rollover risk.

IV. Where Implicit Subsidies Originate: The Political Economy of Last-Resort Lending In its initial stages, an insolvency crisis is observationally indistinguishable from a transitory shortage of aggregate liquidity. The common symptom is that economically significant institutions or sectors suddenly find it impossible to roll over their debts on 
profitable terms. Established central-banking practice is to take action that buys time for bank staff to determine the fundamental sources of the distress. This is done by announcing a willingness to lend freely to banks in desperate circumstances on a collateralized basis at a penalty rate.

Last-resort lending represents the first line of defense against an emerging national or global crisis. But it must be understood that this crisis-management strategy unfolds in a politically charged atmosphere: one that highlights the goal of minimizing exposure to blame and regret. Few top policymakers are willing to risk being blamed by themselves or others for embracing policies that industry propaganda would characterize as escalating a bad situation.

Myopic blame avoidance is supported politically and ethically by three exculpatory norms that are imbedded in the regulatory culture of virtually every country in the world: (1) the mercy norm, (2) the nationalistic norm, and (3) the nonescalation norm. These all-purpose justifications for regulatory intervention conflict with the day-to-day norm of conscientiously tracking and minimizing the long-run social-welfare costs generated by the size and distribution of the subsidies the safety net delivers.

The mercy (or good-Samaritan) norm holds that it is politically unacceptable for regulators to abandon the employees, creditors, and stockholders of institutions they oversee to the vagaries of the market at the first sign of distress. The mercy norm generates a unilateral regulatory right to alleviate sudden attacks of financial "pain.” In particular, it allows safety-net managers to claim without proof that their interventions are merely preventing a sudden liquidity shock from destroying institutions whose fundamentals are sound. 
The nationalistic norm embodies a duty of loyalty to domestic institutions and even to foreign firms that accept responsibility for making markets in domestic bonds. Safetynet managers face a politically enforced de facto obligation to maintain orderly financial markets and to protect institutions headquartered in their jurisdiction by supporting their ability to compete with firms headquartered in foreign lands. The help regulators provide may entail either granting subsidized access to government funds and guarantees, resisting the entry and subsequent local expansion of foreign firms, or paving the way for domestic firms to operate more effectively in foreign territory.

The nonescalation norm holds that it is better to interfere with market efforts to discipline a troubled institution (such as Countrywide Financial or Northern Rock) than to risk turning burgeoning financial turmoil into a national or international disaster. Relying on this norm, safety-net managers can justify lending to insolvent institutions in any distressed sector. They merely have to express a fear that allowing markets to work out what they are free to characterize as a liquidity shock would result in a disorderly liquidation of assets at fire-sale prices and that this event would spread adverse effects throughout the economy in ways that would be impossible to reverse.

These blame-avoidance norms come together in what we might call the First Commandment of Turmoil Management: Be merciful unto important Home-Country Institutions and lead their problems not into contagion with other firms or markets.

\section{$\underline{\text { Policy Implications }}$}

An ideal safety net is one that would fairly and efficiently mitigate the particular monitoring, policing, and coordination difficulties that present themselves to financial institutions, investors, depositors, and taxpayers in the informational, ethical, legal, and 
economic environment of connected countries at a particular time. This means that evolving differences in the size and shape of institutional risk taking call for frequent adjustments in the dimensions of the mesh and in the strength and locations of the net's supporting piers. Politicians have so far been reluctant to involve themselves in the design and operation of regulatory linkages between country safety nets. They have allowed incentive-conflicted top regulators to decide how consistently and how promptly these links should expand to accommodate changes in the market, legal, bureaucratic, and ethical/cultural problems the net is intended to alleviate.

Principal-agent theory tells us that decisions about how to forge and maintain safety-net connections are influenced by incentives that result from political and bureaucratic arrangements that convey to nation-based regulatory officials and financialinstitution stakeholders a collection of net economic rents and burdens.

To fashion a net of the social-welfare maximizing size and strength, decisions bearing on the cost and effectiveness of the net's components must be observable enough to allow watchdogs for outside stakeholders to exert healthy market discipline on protected institutions and healthy budgetary pressure on regulators. Because no hegemonic official feels fully accountable for policy-induced flaws in financialinstitution risk-taking incentives, gaps in the global net are bound to subsidize risk in some venues. Welfare economics tells us that, for global strategies of subsidy control to be more successful, employment contracts must assign top regulators the duty of measuring and managing the global social costs generated by decisions about net design and simultaneously incentivize regulatory personnel to support these duties appropriately. 
Information systems and supervisory technology for monitoring bank capital and risk exposures are deemed to be transparent if they can be analyzed by trained outside experts and evaluated objectively in the financial press. From the point of view of accountability, it is unfortunate that-unlike the splattering of an unlucky or incompetent acrobat—breakdowns in financial safety nets are not immediately visible to the naked eye. This lack of transparency intensifies the conflict between the task of maximizing a net's effectiveness and minimizing the blame that safety-net managers have to absorb for what they do and do not do. Losses can be blamed on events "technically" outside the regulator's span of control or attributed to unforeseeable events transmitted through opaque linkages across national markets.

Precisely because top regulators do not want their professional reputation besmirched by blame for banking scandals or policy mistakes, their authority over reporting protocols can be abused. Having the ability to reduce transparency supports an incentive to distribute implicit subsidies to needy clienteles and to delay insolvency resolution in tough times or tough cases. Such subsidies allow institutions whose insolvency cannot yet be publicly recognized an opportunity to gamble for resurrection at taxpayer and competitor expense (Kane, 1989). To protect the reputations of their agency or its top officers during their particular terms in office, opportunistic regulators may be tempted to conceal and sugarcoat information about emerging difficulties. In particular, policymakers whose term in office is coming to an end may elect not to challenge misleading bank condition reports and might even encourage deceptive information to be entered on balance sheets and income statements. 
Knowing that regulators dislike public criticism and can block the flow of adverse information enables managers and owners of insolvent institutions to exploit regulators' incentive conflicts. Unscrupulous managers can persuade officials to neglect their natural duty of truth-telling. The persistence of options to cover up subsidies and clientele weakness supports the hypothesis that most regulatory cultures give officials $\underline{\text { de }} \underline{\text { facto }}$ authority to conceal or mischaracterize evidence of widespread losses as long as they can assert ex post that forthright statements might have generated or intensified a decline in customer confidence.

Incumbent officials can rely on this untestable claim to lessen their exposure to blame. In principle, the goals of calming public fears and taking cost-effective action to preserve or restore banking solvency can be pursued at the same time, but not with equal effectiveness nor with equal exposure to industry criticism. Depending on the quality of a nation's information and bureaucratic environments, high officials may escape blame for incurring insolvency-resolution costs on their watch by doctoring and suppressing evidence long enough to pass the bill for safety-net losses onto the next generation of regulatory officials. The existence of this reputation-preserving escape hatch undermines the urgency of promptly understanding newly emerging forms of risk-taking and engaging in extensive crisis planning. In turn, myopically underinvesting in forwardlooking activities disposes regulators to conceive of future financial breakdowns as if they were unique events that must always and everywhere be handled in an ad hoc manner.

Common sense tells us that, to cope with continuing financial innovation, politicians must enact legislation that makes regulators accountable for developing and 
regularly reviewing a strategic plan for managing different kinds of crises and for training their staff in the use of their evolving crisis-management protocols. Unless backed up by solid disaster planning, the existence of national safety nets may foster expectations of a secularly expanding propensity to bail out distressed firms. The need for markets to test the limits of this propensity from time to time may generate a series of infrequent, but highly disruptive global crises. Ironically, the more time that passes between crises, the more important crisis planning becomes because fewer financial-institution managers and regulatory personnel will have hands-on experience in dealing with crisis pressures.

\section{Summary Implications}

Goodfriend (1994) underscored the need for someone to define specific principles under which the Fed would and would not be allowed to provide funds to troubled institutions. Intentionally or unintentionally, providing government liquidity support directly to troubled firms rewards firms that have made bad bets. Substituting flexible repurchase agreements for discount-window loans is dangerous because it better masks both the identities of recipient institutions and the size of the benefits they receive.

Editorial cartoonists seem to have understood the distributional effects of the hegemons' policies more clearly than the mainstays of our nation's financial press. One of my favorite cartoons shows a central-bank helicopter lifting a well-dressed banker out of the sea and away from a shark that, despite a might leap, is just able to nip the seat of the banker's pants. A second cartoon shows a lifeguard proudly carrying a shark (that I would label "sponsors of structured securitizations") onto the beach, while leaving dozens of taxpayers and mortgage borrowers foundering in rough seas. 
Ideally, last-resort lenders should be required to model and maximize the present discounted value of the net social-welfare benefits generated by the size and distribution of whatever institutional subsidies their rescues deliver. Within nations, the principle of democratic accountability would dictate that central banks ask their economic staff to estimate in a reproducible manner the social value of these subsidies and to compare the social value of the damage that last-resort lending and capital forbearance avoided with projections of the present and future social costs generated by the subsidy program. If any national government or supranational entity truly wanted to embrace this principle, it would have already enacted legislation to that effect and would have done so in a way that would not politicize decisions about aggregate monetary policy in the process.

It is difficult to imagine that central bankers and industry lobbyists in hub countries would tolerate such legislation today. Unfortunately, it is even harder to imagine that citizens of the hub countries care enough about the possible knock-on effects that nationbased last-resort lending could have on the welfare of citizens in other countries to subject themselves to the cross-country tax-transfer obligations needed to construct an efficient financial safety net of appropriately global dimensions. 
Table 1

\section{LIST OF DESIGNATED PRIMARY DEALERS AUTHORIZED TO BID WHEN REPURCHASE AGREEMENTS ARE OFFERED BY THE FED}

\section{BNP Paribas Securities Corp.}

Banc of America Securities LLC

\section{Barclays Capital Inc.}

Bear, Stearns \& Co., Inc.

Cantor Fitzgerald \& Co.

Citigroup Global Markets Inc.

Countrywide Securities Corporation

Credit Suisse Securities (USA) LLC

Daiwa Securities America Inc.

Deutsche Bank Securities Inc.

Dresdner Kleinwort Wasserstein Securities LLC

Goldman, Sachs \& Co.

Greenwich Capital Markets, Inc.

HSBC Securities (USA) Inc.

J.P. Morgan Securities Inc.

Lehman Brothers Inc.

Merrill Lynch Government Securities Inc.

Mizuho Securities USA Inc.

Morgan Stanley \& Co. Incorporated

Nomura Securities International, Inc.

UBS Securities LLC

Source: Downloaded from the website of the Federal Reserve Bank of New York on September 15, 2007. 
Figure 1

\section{Overnight Interest Rates}

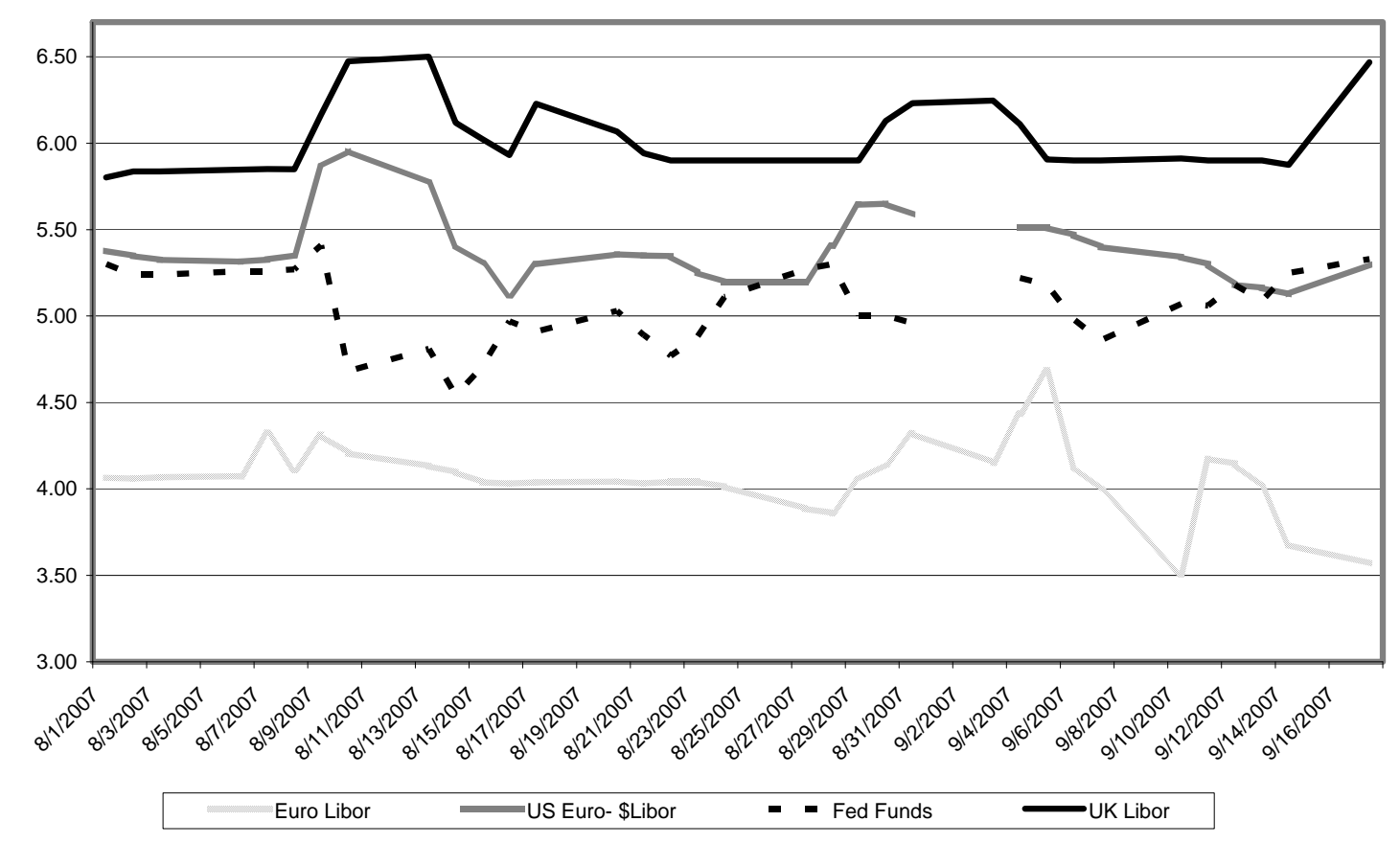

Source: Compiled by Robert A. Eisenbeis from data on the websites of The FinancialTimes and Federal Reserve Bank of New York. 


\section{Figure 2}

\section{Outstanding Commercial Paper (Weekly)}

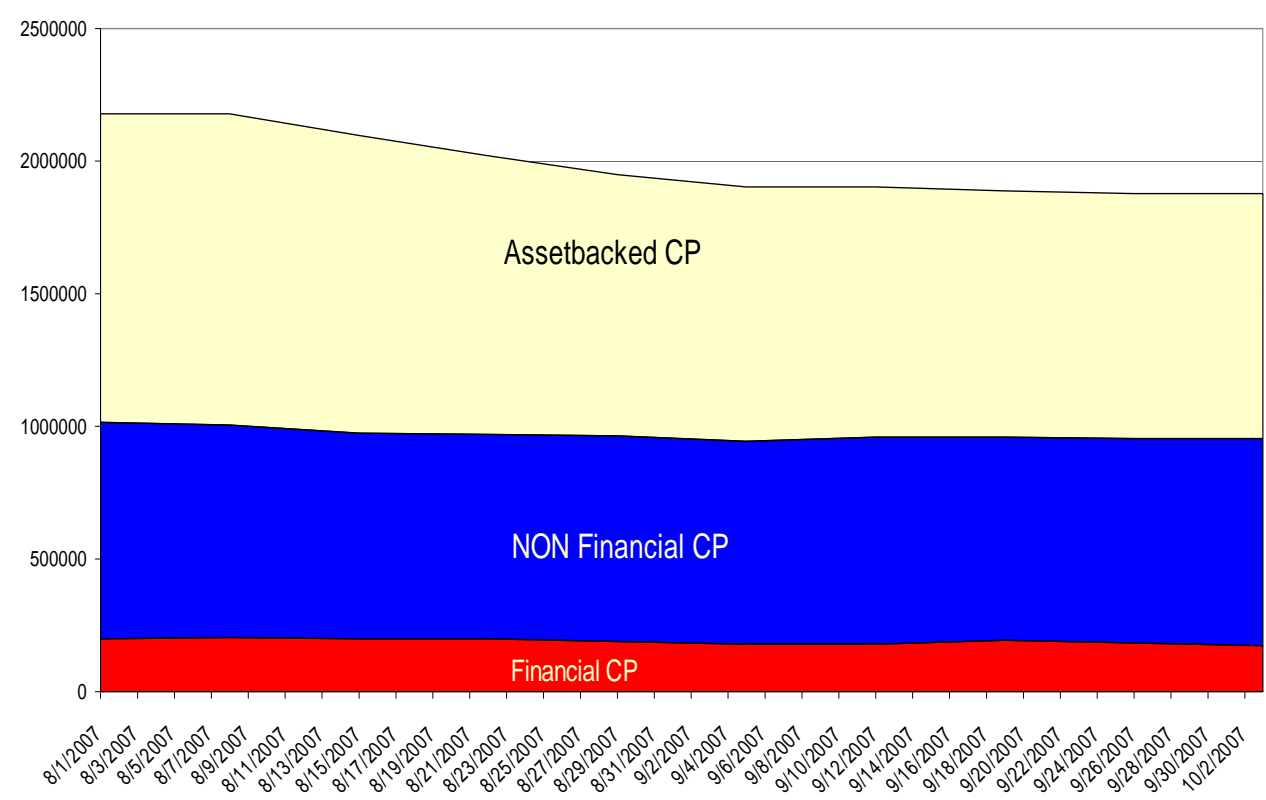

Source: Compiled by Robert A. Eisenbeis from data on the website of the Federal Reserve Bank of New York. 
Figure 3

\section{Daily Value of Newly Issued Overnight Commercial Paper}

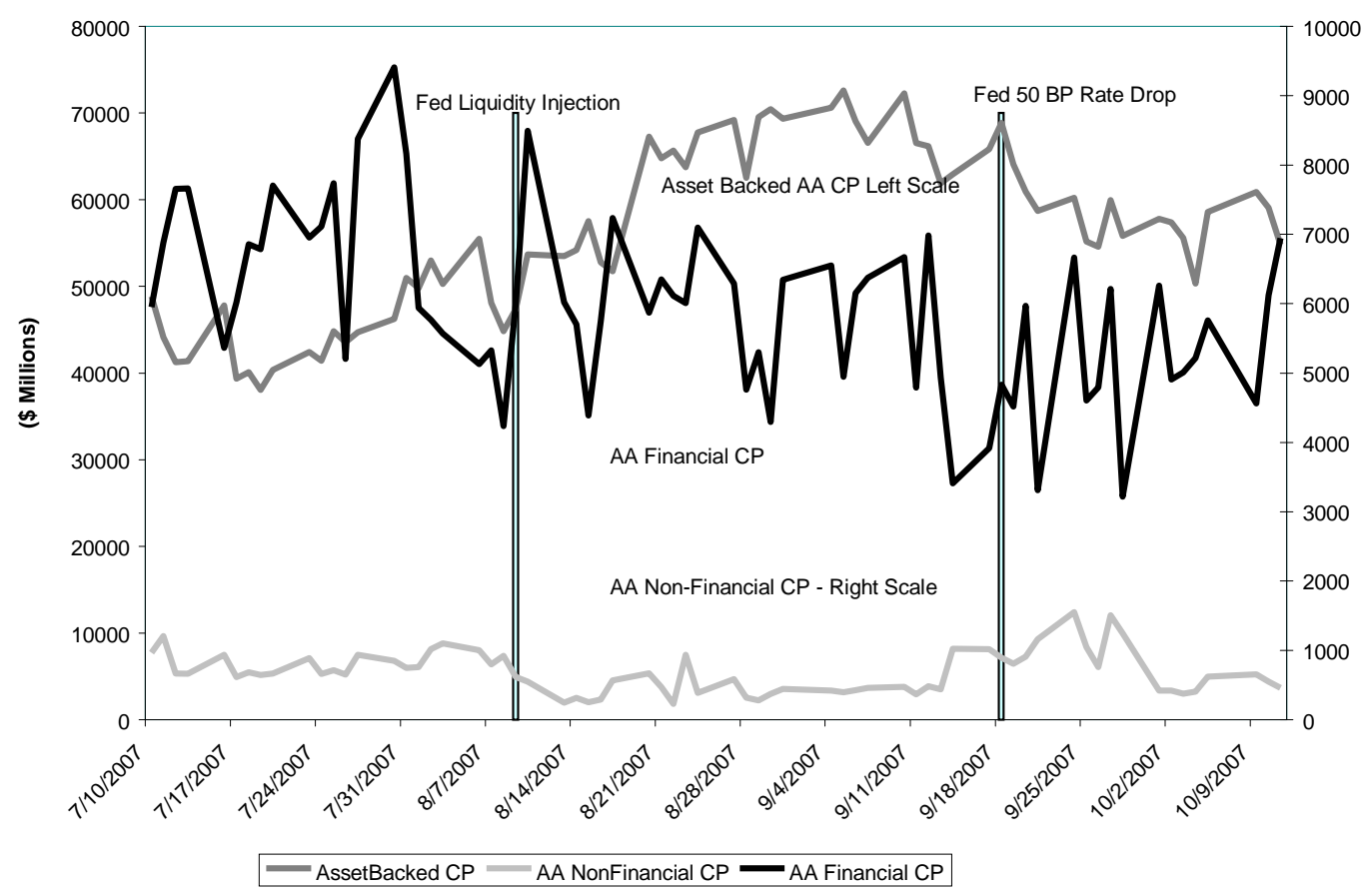

Source: Compiled by Robert A. Eisenbeis from data on the website of the Federal Reserve Bank of New York. 


\section{$\underline{\text { REFERENCES }}$}

Bagehot, Walter, 1873. Lombard Street: A Description of the Money Market (reprinted, Dodo Press, 2006).

Bordo, Michael, 1992. “The Lender of Last Resort: Some Insights from History”, in George Kaufman (ed.) Research in Financial Services: Public and Private Policy, Vol 1.

Carnell, Richard, 1993. “The Culture of Ad Hoc Discretion,” in George Kaufman and Robert Litan (ed.), Assessing Bank Reform: FDICIA One Year Later, Washington: Brookings Institution, pp. 113-121.

Diamond, Douglas, 1984. “Financial Intermediation and Delegated Monitoring,” Review of Economic Studies, 51(July), pp. 343-414.

Dudley, William C., 2007. “May You Live in Interesting Times,” Unpublished Paper Presented at the Federal Reserve Bank of Philadelphia (October 17).

Eisenbeis, Robert, and George Kaufman, 2005. “Bank Crisis Resolution and ForeignOwned Banks.” Economic Review (October), Federal Reserve Bank of Atlanta.

Goodfriend, Marvin, 1994. "Why We Need an ‘Accord’ for Federal Reserve Credit Policy: A Note,” Journal of Money, Credit and Banking, 26(August, Part 2), pp.572-580.

Jensen, Michael C., and William Meckling, 1976. “Theory of the Firm: Managerial Behavior, Agency Costs, and Ownership Structure,” Journal of Financial Economics, 3(June), pp. 305-360.

Kane, Edward J., 1989. The S\&L Insurance Mess: How Did It Happen? Washington: The Urban Institute Press. 
, 2000. "Designing Financial Safety Nets to Fit Country Circumstances.”

(unpublished). , 2004. "Financial Regulation and Bank Safety Nets (in Spanish)",

Papeles de Economia Española, 101, pp. 34-63.

La Porta, Rafael; Florencio Lopez-de-Silanes, Andrei Shleifer, and Robert W. Vishny, 1998. “Law and Finance,” Journal of Political Economy, 106 (December), pp. 1113-1155.

Schieritz, Mark, and Gerrit Wiesmannin, 2007. “British Banks Scoop Up ECB Cash,” Financial Times (September 14).

Thornton, Henry, 1802. An Enquiry into the Nature and Effects of the Paper Credit of

Great Britain. New York: Farrar \& Rhinehart, 1939.

Todd, Walker F., 2002. "Central Banking in a Democracy: The Problem of the Lender of the Last Resort,” in Patricia M. McCoy (ed.), Financial Modernization after Gramm-Leach-Bliley, Newark, NJ: Matthew Bender.

Wojcik, Dariusz, 2007. “The International Finance Index and Its Derivatives,” Oxford: Oxford University Centre for the Environment, Working Papers in Employment, Work and Finance: WPG 07-12 (July). 